\title{
A New Type of Diffusion Cell for Organic Solutions
}

\author{
Ichiro Noda, Satoshi Goto, and Mitsuru Nagasawa \\ Department of Synthetic Chemistry, Nagoya University, \\ Chikusa-ku, Nagoya, Japan.
}

(Received April 10, 1976)

\begin{abstract}
A new type of diffusion cell for organic solutions was constructed by using the method of optical contact. The cell was found to be almost free from strain by examining the distortion of the Rayleigh fringe patterns. Diffusion coefficients of several samples measured by this cell agreed with the reported values within experimental errors.
\end{abstract}

KEW WORDS Diffusion / Diffusion Cell / Frictional Coefficient /

The Rayleigh interference method is one of the standard and most sensitive techniques for measuring diffusion coefficients in solutions, ${ }^{1}$ though a new technique using quasielastic light scattering has been developed recently. ${ }^{2}$ To measure diffusion coefficients in organic solutions by the Rayleigh interference method, we usually use a cell with two channels, one of which is called the diffusion channel and the other the reference channel. A sharp boundary between solution and solvent is formed in the former channel while the latter is filled with solvent.

Several types of diffusion cells for organic solutions have been reported. ${ }^{1,3-6}$ One of the most important problems in designing a diffusion cell is to protect the window plates from strain, which may be produced when the cell is assembled by adhesives or other methods. In the present paper, we report a new type of cell constructed by using the method of optical contact. This cell is found to be almost free from strain.

\section{DIFFUSION CELL}

The cell consists of two quartz plates and a central quartz block. Their dimensions are shown in Figure 1a. The central block has two channels, the diffusion and reference channels. The former channel has one hole at both the top and the bottom to allow the formation of a diffusion boundary, while the latter has only one hole at the top for filling with solvent. Both sides of the central block and one side of the two quartz plates are ground flat to within a tenth of a wavelength of light.

If they are put together without an adhesive as

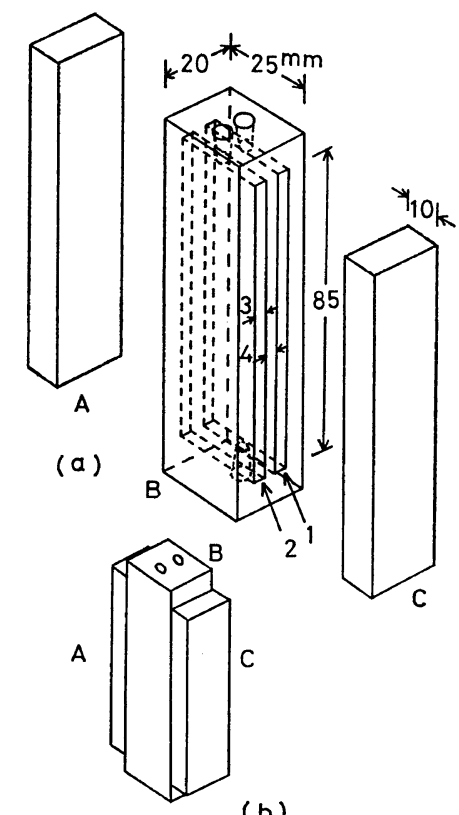

Figure 1. The diffusion cell: A, C, quartz plates; B, central quartz block with diffusion channel (1) and reference channel (2). 


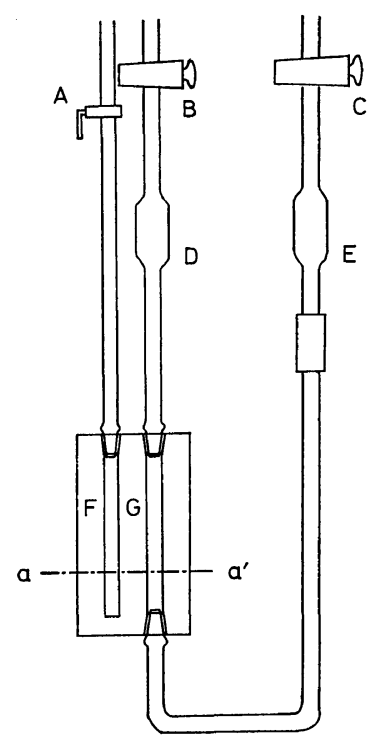

Figure 2. Connections for solution-filling and boundary-sharpening: A, B, C, cocks for filling and sharpening; $\mathrm{D}$, solvent container; $\mathrm{E}$, solution container; F, reference channel; G, diffusion channel.

shown in Figure 1b, a liquid-tight cell is obtained, which can be used for diffusion experiments with both aqueous and organic solvents. All parts were made by Tokyo Kodenshi Kogyo Co., Ltd. Tokyo.

The cell is placed in a holder with a mask having two pairs of reference slits. ${ }^{1}$ The cell holder is fixed in the cell rack for the Beckman/ Spinco Model H Electrophoresis-Diffusion Instrument. Tubes with containers and stop cocks are connected to the central block with ground glass joints, as shown in Figure 2. Two types of greases were used to seal the ground glass joints in the cases of organic solutions. The end sides of the tapered glass tube were coated with a dextran grease which sealed off the organic solutions and the other sides were coated with a silicone grease which sealed off the water in the thermostat.

The boundary between solution and solvent was formed in the diffusion channel by adding the solution and solvent through the glass tubes; it was then sharpened by sucking the solution at the boundary using a long syringe needle, as suggested in the instruction manual of the Beckman/Spinco Model H. ${ }^{7}$

\section{TEST OF OPITICAL HOMOGENEITY OF CELL}

To examine the optical homogeneity of the cell, we took photographs of the Rayleigh fringe patterns on Fuji panchromatic plates by filling the two channels with cyclohexane or water at $25 \pm 0.01^{\circ} \mathrm{C}$. The optical system used was that of the Beckman/Spinco Model H ElectrophoresisDiffusion Instrument. Deviations of the fringes from a straight line on the plate were measured with a microcomparator of Shimadzu Seisakusho. As shown in Figure 3, the region about 4-cm long above the bottom side of the cell is optically homogeneous within 0.01 fringe, which is within the sensitivity of the Rayleigh interference method. The distortion of the fringe patterns on the upper side of the cell may have been caused by internal strains in the quartz plates themselves. To measure the diffusion coefficient, therefore, the boundary was formed at the center of the optically homogeneous part of the cell (line aa' in Figure 2).

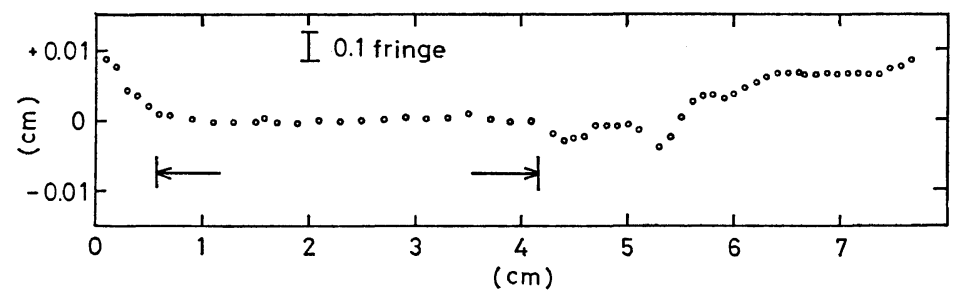

Figure 3. Test of optical homogeneity of the cell. Cyclohexane is placed in both diffusion and reference channels. The ordinate denotes the deviation of the fringes from a straight line. The abscissa denotes the distance from the bottom of the cell. 


\section{A New Type of Diffusion Cell for Organic Solutions}

\section{MEASUREMENTS OF DIFFUSION COEFFICIENTS}

For further tests of the cell we measured diffusion coefficients of several substances whose diffusion coefficients were already known. They were $\mathrm{NaCl}$ in $0.05-M$ aqueous solution, ${ }^{8} n$ hexane in $\mathrm{CCl}_{4}{ }^{9}$, cyclohexane in $\mathrm{CCl}_{4}{ }^{10}$ and biphenyl in benzene, ${ }^{6}$ all at $25^{\circ} \mathrm{C}$, and nearly monodisperse $\operatorname{poly}(\alpha$-methylstyrene $)$ in cyclohexane at $34.5^{\circ} \mathrm{C}$ (in a $\theta$-solvent). ${ }^{11}$

These samples and solvents were prepared as follows. $\mathrm{NaCl}$ solution: a special grade $\mathrm{NaCl}$ (Katayama Kagaku Kogyo Co., Ltd.) dried at $500^{\circ} \mathrm{C}$ was dissolved in distilled water which had been deionized by passing through a mixed bed ion exchange column. $n$-Hexane: a spectroscopic grade reagent (Tokyo Kasei Kogyo Co., Ltd.) was used without further purification. The purity was higher than $99 \%$ by gas chromatography. Cyclohexane: a first grade reagent (Katayama Kagaku Kogyo Co., Ltd.) was passed through a silica gel column to remove any aromatic compounds and was distilled over metal $\mathrm{Na}$ under argon atmosphere. No impurities were detected by U.V. spectroscopy or gas chromatography. Biphenyl: an ultrapure grade reagent (Tokyo Kasei Kogyo Co., Ltd.) purified by a zone refining method was used without further purification. The purity was higher than $99 \% . \quad \mathrm{CCl}_{4}$ : a spectroscopic grade reagent (Wako Pure Chemical Industries, Ltd.) was used without further purification. Benzene: a Merck AG reagent was distilled over metal $\mathrm{Na}$ under argon atmosphere. No impurities were detected by gas chromatography. Monodisperse $\operatorname{poly}(\alpha$-methylstyrene): this sample was prepared by an anionic polymerization. The weight-average molecular weight, $\bar{M}_{w}$, was

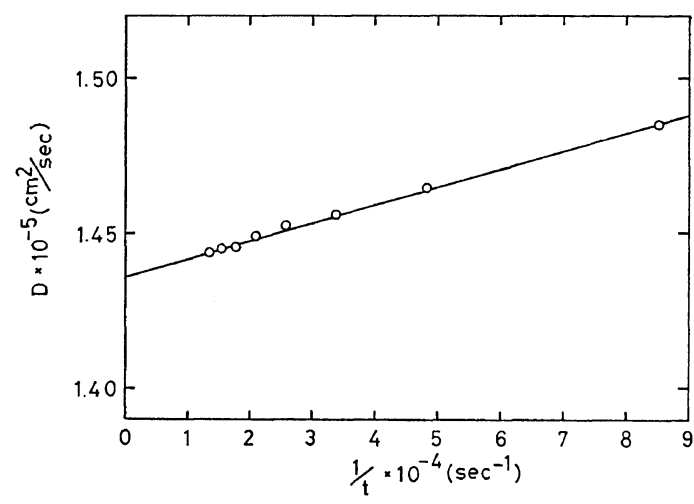

Figure 4. An example of plots for determining the diffusion coefficient. The sample is $n$-hexane in $\mathrm{CCl}_{4}$ (see experiment 2 in Table $\mathrm{I}$ ).

Table I. Diffusion experiments

\begin{tabular}{|c|c|c|c|c|c|c|}
\hline \multirow{2}{*}{\multicolumn{2}{|c|}{ Systems }} & \multirow{2}{*}{$\bar{C}^{\mathrm{a}}$} & \multirow{2}{*}{$J^{\mathrm{b}}$} & \multirow{2}{*}{$\begin{array}{l}\text { Initial time correction } \\
\qquad \Delta t, \mathrm{sec}\end{array}$} & \multicolumn{2}{|c|}{$D \times 10^{5}, \mathrm{~cm}^{2} / \mathrm{sec}$} \\
\hline & & & & & Exptl & Ref \\
\hline 1. & $\begin{array}{l}\mathrm{NaCl}-\mathrm{H}_{2} \mathrm{O} \\
\left(25^{\circ} \mathrm{C}\right)\end{array}$ & $0.05(\mathrm{~mol} / \mathrm{l})$ & $96.4_{4}$ & 50 & $1.50_{5}$ & $1.50_{7}^{8}$ \\
\hline 2. & $\begin{array}{l}n \text {-Hexane- }-\mathrm{CCl}_{4} \\
\left(25^{\circ} \mathrm{C}\right)\end{array}$ & $0.202_{4}(g / \mathrm{d} l)$ & $49.1_{6}$ & 40 & $1.43_{6}$ & $1.46_{7}^{9}$ \\
\hline 3. & $\begin{array}{l}\text { n-Hexane- }-\mathrm{CCl}_{4} \\
\left(25^{\circ} \mathrm{C}\right)\end{array}$ & $0.217_{3}$ & $54.0_{1}$ & 43 & $1.45_{1}$ & $1.46_{7}^{9}$ \\
\hline 4. & $\begin{array}{l}\text { Cyclohexane- } \mathrm{CCl}_{4} \\
\left(25^{\circ} \mathrm{C}\right)\end{array}$ & $0.290_{3}$ & $15.8_{4}$ & 56 & $1.22_{0}$ & $1.219^{10}$ \\
\hline 5. & $\begin{array}{l}\text { Biphenyl-Benzene } \\
\left(25^{\circ} \mathrm{C}\right)\end{array}$ & $0.187_{9}$ & $40.5_{3}$ & 62 & $1.50_{1}$ & $1.55_{0}^{6}$ \\
\hline 6. & $\begin{array}{l}\text { Poly }(\alpha \text {-methylstyrene })- \\
\text { Cyclohexane } \\
\left(34.5^{\circ} \mathrm{C}\right) \\
\bar{M}_{w}=20.4 \times 10^{4}\end{array}$ & $0.125_{3}$ & $43.0_{4}$ & 143 & $3.00 \times 10^{-2}$ & $3.05 \times 10^{-2} \mathrm{c}, 11$ \\
\hline
\end{tabular}

a $\bar{C}$ is the average initial concentration.

b $J$ is the total number of the Rayleigh fringes.

c $D$ is calculated from the sedimentation coefficient $S$ of the sample in the $\theta$ solvent at the same concentration, using the relationship $D=R T S / M(1-\bar{v} \rho)$, where $\rho$ is the destiny of the solvent and $M$ and $\bar{v}$ are the molecular weight and the partial specific volume of the polymer, respectively. 
$20.4 \times 10^{4}$ daltons and the ratio of $\bar{M}_{w}$ to the number-average molecular weight $M_{n}$ was close to 1.00 .

Diffusion experiments were carried out according to the standard procedure for the Beckman/ Spinco Model H Electrophoresis-Diffusion Instrument. Eight photographs were taken at intervals during each diffusion process. Fuji process panchromatic plates and Oriental SS Type Pan plates were used to record the patterns. The fringe patterns were measured with a microcomparator. The methods of Longsworth $^{12}$ and Creeth ${ }^{13}$ were used to obtain the apparent diffusion coefficients from the Rayleigh fringe patterns. The apparent diffusion coefficients calculated at different times are plotted against inverse of time, $1 / t$, as shown in Figure 4. The diffusion coefficient can be obtained as the intercept at $1 / t=0$, while the slope of the straight line gives the initial time correction $\Delta t$.

All the experimental data are shown in Table I. The diffusion coefficients obtained from the present experiments are in satisfactory agreement with the data reported previously.

Acknowledgment. We wish to thank Mr. T. Yamaguchi, Tokyo Kodenshi Kogyo Co., Ltd., who constructed the present diffusion cell.

\section{REFERENCES}

1. H. Svensson and T. E. Thompson in "A Laboratory Manual of Analytical Methods of Protein Chemistry", Vol. 3, P. Alexander and R. J. Block, Ed., Pergamon Press, New York, N.Y., 1961, Chapter 3.

2. B. Chu, "Laser light Scattering" Academic Press, New York, N.Y., 1974.

3. C. S. Calwell, J. R. Hall, and A. L. Bahle, Rev. Sci. Instr., 28, 816 (1957).

4. R. K. Dewan and K. E. Van Holde, J. Chem. Phys., 39, 1820 (1963).

5. B. N. Tsvetkov, B. E. Eskin, and E. Y. Frenkel, "Structure of Macromolecules in Solutions", Nauka, Moscow, 1964.

6. L.-O. Sundelöf, Arkiv Kemi, 25, 1 (1965).

7. Beckman/Spinco Model H Electrophoresis-Diffusion Instrument Instruction Manual, Beckman Spinco Division.

8. R. H. Robinson and H. A. Stokes, "Electrolyte Solutions" Butterworth, London, 1965.

9. L. G. Longsworth, J. Colloid Interfac. Sci., 22, 3 (1966).

10. S. F. Sum, R. J. Beshimshe, and K. E. Van Holde, J. Amer. Chem. Soc., 89, 6417 (1967).

11. I. Noda, K. Mizutani, and T. Kato, to be published.

12. L. G. Longsworth, J. Amer. Chem. Soc., 74, 4155 (1952).

13. J. M. Creeth, ibid., 77, 6428 (1955). 